\title{
ADOPTION CONSTITUTIONALISM: ANiSHINAABE CITIZENSHIP LAW AT FORT WILLIAM FIRST NATION
}

\author{
DAMIEN LEE*
}

\begin{abstract}
This article explores familial jurisdiction over citizenship, using the study of Anishinaabe citizenship practices in the Fort William First Nation, through the lens of adoption stories. The author highlights how families are able to use adoption to regulate citizenship, bringing new citizens into the nation, while also selecting those who do not belong. The familial system of affirmation is different than a Certificate of Indian Registration and requires collective action, rather than individual self-determination. Belonging at Fort William is further argued to not depend solely on blood quantum, Indian status, or band membership but, rather, depends on active community determination and accountability to the community on an on-going basis. Seen this way, adoption narratives reveal a citizenship order that challenges Canada's claimed jurisdiction to discern who belongs with First Nations.
\end{abstract}

\section{TABLE OF CONTENTS}

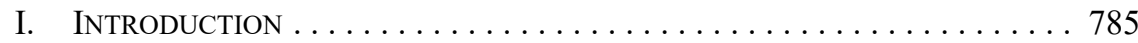

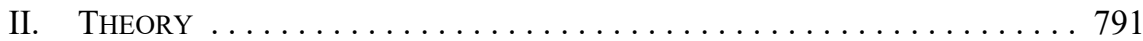

A. TREATY AND Adoption CONSTITUtionALism $\ldots \ldots \ldots \ldots \ldots 791$

III. RESEARCH AT Fort William First NATION . . . . . . . . . . . . . . 796

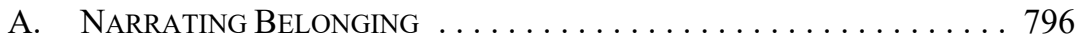

B. Provisional Consensus $\ldots \ldots \ldots \ldots \ldots \ldots \ldots \ldots \ldots \ldots \ldots \ldots$

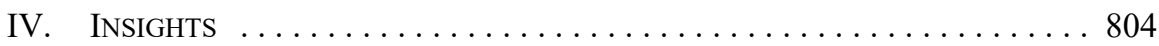

A. Collaboration and Renewal . . . . . . . . . . . . 804

B. Belonging Is Co-Constitutive:

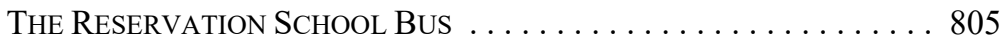

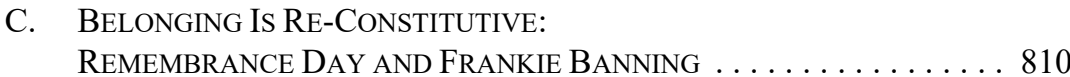

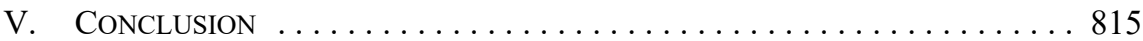

\section{INTRODUCTION}

The genesis of this article can be traced back to July 2012. I had just completed the first year of my doctoral studies in Winnipeg, and took a short trip home to Fort William First Nation (Fort William) ${ }^{1}$ to meet with my chief and council about my membership in the band. Earlier that month, I had applied for band membership under our community's membership code ${ }^{2}$ and was given the opportunity to speak to my request. My father and I went to the band office at the scheduled time, and awaited our turn to speak. What happened next shaped the next six years of my life.

PhD, Assistant Professor, Department of Sociology, Ryerson University; Associate Fellow, Yellowhead Institute.

1 In this article, I use "Fort William" or "Fort William First Nation" in reference to the social and geographical community itself. On the other hand, I use the term "Fort William Indian band" when writing about the governance structure established under the federal Indian Act, RSC 1985, c I-5.

2 Fort William Indian band, Band Membership Code (1987) [Membership Code]. This code was enacted under section 10 of the Indian Act, ibid. I had begun discussions with my band regarding membership in the early $2000 \mathrm{~s}$, but was not made aware of our 1987 membership code until 2011. 
My membership application was based on adoption, and dad explained how he used customary law to bring me into the MacLaurin clan in $1980 .^{3}$ Almost immediately, individual council members then began to bounce my request around like a volleyball: could customary adoption really equate to band membership? Was adoption defined in the 1987 band membership code? Was I registered as an Indian under the Indian Act? Should this even matter? My father tried to intervene, to explain how other people had been made band members at Fort William based on adoption in the past. But his voice was drowned out. My request seemed to have opened a can of worms.

The melee was shut down with a simple Internet search. Requesting everyone be quiet for a moment, the chief turned to his administrative assistant and asked her to search the Internet to see if customary adoption could result in membership in an Indian band. The room sat quiet. Half a minute later he reported back: they could not find evidence that Fort William or any Indian band could make someone a band member as a result of customary adoption. My father and I were told that nothing could be decided that day pending further information on adoption and membership, and my request was deferred indefinitely.

I was stunned. How could an Internet search be the process for discerning belonging at Fort William First Nation? How could my father's use of Anishinaabe customary law be ignored so easily? What about the membership code? Surely it could provide recourse on this matter. Moreover, Fort William First Nation has a long history of making people belong through adoption, ${ }^{4}$ and its people have long argued in support of this. ${ }^{5}$ The Chief's words did not reconcile with reality, history, or practice. While my father and I were confused, I left the meeting with something important: I had found the focus of my PhD studies. I returned to Winnipeg determined to write a dissertation with the sole purpose of better informing ongoing conversations about belonging at Fort William First Nation. ${ }^{6}$ This article, along with related work I have done since defending my dissertation in $2017,{ }^{7}$ continues along those lines.

3 There are several large family groups at Fort William First Nation, and the MacLaurins are one of the largest. While I go by Damien Lee today, the name my parents used for me until about 1988 was Damien MacLaurin; my elementary school records reflect this. I began going by Damien Lee by choice, simply because I had noticed this was the name written on my Ontario birth certificate. I was a somewhat pedantic child.

$4 \quad$ See the discussion about Frankie Banning in Part IV.C below, as well as Figures 3 and 4 herein. Moreover, the knowledge holders I reference below also speak to the on-going practice of using customary adoption at Fort William First Nation.

5 See the submission of Charles MacLaren, Canada, Department of Indian Affairs and Northern Development, Report of the Indian Act Consultation Meeting: Fort William, Ontario (1968) at 57-59.

Damien Lee, “Because Our Law Is Our Law”: Considering Anishinaabe Citizenship Orders Through Adoption Narratives at Fort William First Nation (PhD Thesis, University of Manitoba Department of Native Studies, 2017) [unpublished], online: <hdl.handle.net/1993/32277> [Lee, Adoption Narratives]. Fort William First Nation, "Weekly Newsletter" (November 2017), online: <https://fwfn.com/wpcontent/uploads/2017/11/Week-of-November-13-19.pdf $>$. In addition to my dissertation being publicly available online through the University of Manitoba Libraries website, I also held a feast in Fort William First Nation for community members on 13 November 2017. I presented my dissertation's major findings at the feast, and had an illuminating discussion about Anishinaabe law, adoption, and belonging with the 15 or so people in attendance that night. 
Belonging, for First Nations in Canada, is a site fraught with tension, contradiction, and a messiness resultant from nearly 170 years of colonial interference. ${ }^{8}$ Beginning in 1850 , settler colonialists began regulating Indigenous legal orders for discerning belonging through legislation that had little to do with inherent Indigenous laws. ${ }^{9}$ These laws initiated a "dismembering" of Indigenous communities whereby eventually thousands of individuals were removed from their communities, particularly through gendered discrimination. ${ }^{10}$ Just as significantly, said laws instituted a way of thinking about Indianness and belonging that has not come to co-construct Indigeneity itself, ${ }^{11}$ but also obfuscates the continued existence of inherent Indigenous legal orders. ${ }^{12}$

This latter point is one of the most important elements of settler colonialism in the Canadian context. While settler colonialism has been effective at destroying some elements of Indigenous legal orders, it has also been successful in obfuscating their continued practice. ${ }^{13}$ Indigenous legal orders have survived settler colonial violence, even if they exist today in "lacerated" form. ${ }^{14}$ As Val Napoleon puts it, "despite the damage to our legal orders,

"An Act for the better protection of the Lands and Property of the Indians in Lower Canada, 1850" in Thomas Isaac, ed, Pre-1868 Legislation Concerning Indians: A Selected \& Indexed Collection (Saskatoon: Native Law Centre, University of Saskatchewan, 1993) 40; Indian Act, supra note 1.

9 Such regulation continues today in the form of the Indian Act, ibid. I say "little to do with" rather than "nothing to do with" inherent Indigenous laws here because the 1850 legislation cited above actually was relatively more reflective of Indigenous systems of belonging than the majority of Indian law since. For example, section V of An Act for the better protection of the Lands and Property of the Indians in Lower Canada, SPC 1850, c 42 imagined belonging in ways that included adoption, marriage, and the authority of the "Tribe or Body of Indians" to claim people more generally. These modes of determining belonging are similar to my understanding of inherent Anishinaabe citizenship law, that is, families play a key role in making people belong (or not). I should not be misunderstood to mean that this Act was co-written with Indigenous nations; rather, I leave open the possibility for colonialists writing such law in a way that attempted to reflect Indigenous citizenship practice at the time. Historical research on how such criteria were originally developed would be a welcome addition to Indian policy scholarship.

10 Bonita Lawrence, "Real” Indians and Others: Mixed-Blood Urban Native Peoples and Indigenous Nationhood (Vancouver: UBC Press, 2004) at 27; Canada, Office of the Parliamentary Budget Officer, "Bill S-3: Addressing Sex Based Inequities in Indian Registration" (Ottawa, 5 December 2017) at 6-7; "Bill S-3, An Act to amend the Indian Act," Debates of the Senate, 42nd Parl, 1st Sess, vol 150, No 156 (7 November 2017) at 4079-88, online: < https://sencanada.ca/en/content/sen/chamber/421/debates/ 156db 2017-11-07-e\#41>; "Bill S-3: Removing Sex-Based Inequities From the Indian Act," Senate GRO (5 December 2017), online: <https://senate-gro.ca/new-laws/s-3-indian-act/>. With regards to Indian registration specifically, current numbers suggest that more than 670,000 individuals have been removed from their respective Indian bands since 1869 (see Office of the Parliamentary Budget Officer, ibid). It is important to note that until 1985, membership in an Indian band was tied directly to whether one was registered as an Indian under the Indian Act, ibid.

11 Lawrence, ibid at 25.

12 See Val Napoleon, "Thinking About Indigenous Legal Orders" in René Provost \& Colleen Sheppard, eds, Dialogues on Human Rights and Legal Pluralism (Dordrecht: Springer, 2013) 229 [Napoleon, "Indigenous Legal Orders"]; Hadley Louise Friedland, The Wetiko Legal Principles: Cree and Anishinabek Responses to Violence and Victimization (Toronto: University of Toronto Press, 2018) at 15; Johnny Mack, "Hoquotist: Reorienting Through Storied Practice" in Hester Lessard, Rebecca Johnson \& Jeremy Webber, eds, Storied Communities: Narratives of Contact and Arrival in Constituting Political Community (Vancouver: UBC Press, 2011) 287. As Friedland puts it: "Indigenous law can be hard to see when we are used to seeing law as something the Canadian government or police make or do. Some people may have even been taught that Indigenous people did not have law before white people came here. This is a lie" (ibid at 3). I return to these points throughout this article.

13 Napoleon, "Indigenous Legal Orders," ibid.

14 Audra Simpson, "The Chiefs Two Bodies: Theresa Spence and the Gender of Settler Sovereignty" (Paper delivered at the RACE Network's 14th Annual Critical Race and Anticolonial Studies Conference, University of Alberta, 2014); Edward Benton-Banai, The Mishomis Book: The Voice of the Ojibway (Hayward: Indian Country Communications, 1988) at 89-113; Mack, supra note 12 at 295. Other Indigenous scholars have reflected on the state of some Indigenous legal systems after generations of settler colonial attack. For example, Johnny Mack writes "Hoquotist is a Nuu-chah-nulth metaphor used to describe a disoriented person or people. It refers to a person whose canoe is overturned. It appropriately describes the disconnection that currently exists between the Nuu-chah-nulth people and their stories. By this, I mean to say that our stories are still with us, but they are not in working order" 
Indigenous peoples continue to act on historic legal obligations in modern forms wherever they can." ${ }^{15}$ Paradoxically, though, some within First Nations contexts assume that Indigenous laws exist only to the extent that they can be recognized by Canadian law; Indigenous citizenship orders offer a case in point: many assume that belonging is something to be affirmed or denied only by the Indian $A c t^{16}$ or its band membership provisions, ${ }^{17}$ rather than something guided by Indigenous legal orders. ${ }^{18}$ This article challenges such thinking by offering evidence of the continued existence and practice of Anishinaabe citizenship law in my community.

To be sure, work is being done by Indigenous and non-Indigenous legal scholars that supports such claims. Scholars such as John Borrows, Val Napoleon, James Youngblood Henderson, Hadley Friedland, Robert Clifford, Aaron Mills, and Johnny Mack, to name only a few, are challenging perceptions in ways that make clear the fact that Indigenous legal orders not only continue to exist, but continue to be useful and valid. ${ }^{19}$ Whether it be about demonstrating the use of Indigenous law in relation to land use, treaties, constitutionalism, justice, the family, or other issues, these and other scholars are exploring ways to both see and apply legal orders in the present. ${ }^{20}$ Furthermore, building an understanding of these legal orders cannot be done by using the interpretative framework of another legal order. ${ }^{21}$ What this tells me is that the Canadian juridical landscape is pluralistic in nature. There is no "one law for all" in Canada, but a set of legal orders that share the same space and at times bump up against each other.

(ibid at 295). Edward Benton-Banai tells a story about Anishinaabe knowledge being hidden in the side of a cliff as a means to protect it from colonialism (ibid). Whether lacerated, overturned, or hidden, the key is to note that Indigenous knowledges and legal systems have not died. Settler colonialism has not won.

Napoleon, "Indigenous Legal Orders," supra note 12 at 237.

Supra note 1.

Ibid, s 10. See Lawrence, supra note 10 at 221; Stewart Clatworthy, Indian Registration, Membership and Population Change in First Nations Communities (Ottawa: Minister of Indian Affairs and Northern Development, 2005). Moreover, many of the Indian bands in Canada that wrote their own membership codes in accordance with section 10 of the Indian Act actually made membership in the band contingent on a person being registered as an Indian under section 6 of the Indian Act. See Clatworthy, ibid. Lawrence, ibid.

John Borrows, Freedom and Indigenous Constitutionalism (Toronto: University of Toronto Press, 2016) [Borrows, Constitutionalism]; Napoleon, "Indigenous Legal Orders," supra note 12; Val Napoleon, Ayook: Gitksan Legal Order, Law, and Legal Theory (PhD Dissertation, University of Victoria Faculty of Law, 2009) [unpublished]; James Youngblood Henderson, First Nations Jurisprudence and Aboriginal Rights: Defining the Just Society (Saskatoon: Native Law Centre, University of Saskatchewan, 2006) [Henderson, First Nations Jurisprudence]; Friedland, supra note 12; Mack, supra note 12; Aaron Mills, "The Lifeworlds of Law: On Revitalizing Indigenous Legal Orders Today" (2016) 61:4 McGill LJ 847; Robert YELḰÁTTE Clifford, "WSSÁNEĆ Legal Theory and the Fuel Spill at (Goldstream River)"'(2016) 61:4 McGill LJ 755.

20 See Clifford, ibid; John Borrows, Canada's Indigenous Constitution (Toronto: University of Toronto Press, 2010) [Borrows, Indigenous Constitution]; Henderson, First Nations Jurisprudence, ibid, ch 4; Friedland, ibid; Donald J Auger, The Northern Ojibwe and Their Family Law (DJur Dissertation, Osgoode Hall Law School, York University, 2001) [unpublished].

21 Napoleon, "Indigenous Legal Orders," supra note 12 at 236. See also James (Sákéj) Youngblood Henderson, "Treaty Governance" in Yale D Belanger, ed, Aboriginal Self-Government in Canada: Current Trends and Issues, 3rd ed (Saskatoon: Purich, 2008) at 22. Henderson, writes:

Not only are the Aboriginal concepts of sovereignty and law distinct from the political concepts of Europe or the traditions of civil or common law, they are distinct from the liberal principles and abstract rights used in Charter interpretations of personal rights. The Supreme Court [of

Canada] is aware that neither the British nor the French legal tradition can adequately describe Aboriginal sovereignty, laws, or rights.

And thus, as Napoleon writes, "it is critical to consider these laws from within their cultural and historical perspectives so that they make sense as a part of governance" (ibid at 236). 
In line with this pluralism, law schools at Canadian universities are beginning to make space to teach about Indigenous legal orders. For example, universities are responding to the Truth and Reconciliation Commission of Canada's 94 Calls to Action ${ }^{22}$ in various ways, including making space for students to learn about Indigenous laws rather than viewing Indigenous legal issues simply through the lens of Canadian law. ${ }^{23}$ As evidence of this, in 2018 the University of Victoria, Faculty of Law will accept an inaugural cohort into a new joint degree program in Canadian Common Law and Indigenous Legal Orders, meant to prepare law students to use Indigenous law within common law, and understand how these two legal systems interact. ${ }^{24}$ Moreover, Indigenous knowledge holders continue to teach their nations' laws to those entitled to receive such knowledge. ${ }^{25}$ Yet, despite these points, the resurgence of Indigenous citizenship law faces the challenge of identifying sources of inherent law in ways that limit the reproduction of settler colonial logics of who can belong as Indians. ${ }^{26}$ For example, band membership codes developed in accordance with the provisions of the Indian Act, ${ }^{27}$ or even those developed under self-governance legislation is one thing, but it is important to remember that such forms of belonging differ from the frames of belonging that arise from Indigenous nations' own legal orders due to their sources of authority. The Indian Act traces its authority to Canada's constitutional authority. ${ }^{28}$ By contrast, Indigenous citizenship orders find their authority outside of the state itself - they are sui generis. ${ }^{29}$ However, if Bonita Lawrence is correct in her argument that the Indian Act has produced a way of thinking about Indigeneity that "embeds itself in every attempt to change it" ${ }^{\prime 30}$ - or a discourse - then great care must be taken to anchor the resurgence of Indigenous citizenship orders in their sui generis roots while adapting them to contemporary contexts. Others have pointed to similar traps to be wary of when trying to promote the resurgence of Indigenous legal orders today. ${ }^{31}$

Truth and Reconciliation Commission of Canada: Calls to Action (Winnipeg: TRC, 2015), online: $<$ trc.ca/assets/pdf/Calls to Action English2.pdf $>$ [TRC, Calls to Action].

23 Mills, supra note 19 at $\overline{8} 4 \overline{9}-54$. Mills' work in particular makes clear that including Indigenous legal systems into legal education contexts can be important to Indigenous students learning in these spaces. Sean Fine, "University of Victoria to Launch First-of-its-Kind Indigenous Law Program," The Globe and Mail (21 March 2018), online: <https://www.theglobeandmail.com/canada/article-university-ofvictoria-to-launch-first-of-its-kind-indigenous-law/>; University of Victoria Faculty of Law, "Joint Degree Program in Canadian Common Law and Indigenous Legal Orders JD/JID" (2018), online: $<$ https:// www.uvic.ca/law/about/indigenous/jid/index.php>.

25 See e.g. Damien Lee, "Placing Knowledge as Resurgence" (2012) 6 InTensions J 1, online: <www. yorku.ca/intent/issue6/articles/damienlee.php>; Mills, supra note 19 at 852; Jana-Rae Yerxa, "GiiKaapizigemin Manoomin Neyaashing: A Resurgence of Anishinaabeg Nationhood" (2014) 3:3 Decolonization: Indigeneity, Education \& Society 159, online: < decolonization.org/index.php/des/ article/download/22234>. I am also thinking about knowledge holders I have worked with personally, including my grandmother Geraldine MacLaurin of Fort William First Nation, Marlene Pierre of Fort William First Nation, Doug Williams of Curve Lake First Nation, and Maria Campbell of the Métis Nation, among others.

26 Napoleon, "Indigenous Legal Orders," supra note 12 at 236. Napoleon writes: "[ $[$ ] learn to recognize [Indigenous laws] because they can be implicit, informal, and decentralized." Moreover, the "logics" I refer to here include, inter alia, strict focus on blood quantum, androcentrism, and heteronormativity.

Supra note 1 .

Constitution Act, 1867 (UK), 30 \& 31 Vict, c 3, reprinted in RSC 1985, Appendix II, No 5, s 91(24)

James (Sákéj) Youngblood Henderson, "Sui Generis and Treaty Citizenship" (2002) 6:4 Citizenship Studies 415 [Henderson, "Sui Generis"].

Lawrence, supra note 10 at 25.

See e.g. Mack, supra note 12 at 293; as he puts it: "if we are to take our stories seriously, I think we must turn ourselves to the task of releasing from the imperial story. This is a tricky task: as now imperialized subjects, we can easily become trapped in institutions and processes that can potentially cycle our emancipatory strivings back into the very imperial framework we intend to escape." 
The purpose of this article, therefore, is to describe my understanding of Anishinaabe citizenship law as it is practiced in my community. Drawing on my dissertation research, ${ }^{32}$ I argue here that Anishinaabe citizenship law not only continues to be practiced at Fort William, but in fact demonstrates a complex citizenship governance system that continues to function. In order to avoid the issue raised above regarding reproducing Indian Act discourse, this article considers inherent Anishinaabe citizenship law, not through band membership provisions or the ways in which "Indian status" has been imagined in Canadian law, ${ }^{33}$ but rather through the ways in which Fort William knowledge holders narrate belonging as a result of adoption. While this article is not about adoption per se, it allows me to demonstrate the continued existence and practice of Anishinaabe citizenship law. Here, I use adoption as a way to see how some families at Fort William continue to practice their inherent legal order to claim individuals outside and alongside Indian Act-based law such as band membership. This is useful considering that one of the challenges Indigenous nations face today is to recognize "implicit, informal, and decentralized" practices as law. ${ }^{34}$ As someone who has no "Indian blood" 35 yet belongs with the Anishinaabeg at Fort William, I have a sense as to how Anishinaabe citizenship law continues to be practiced. While I eventually became a member of the Fort William Indian band, ${ }^{36}$ I belong with Anishinaabeg because of the continued practice of Anishinaabe law, not in spite of it. ${ }^{37}$ Others might see this differently. ${ }^{38}$

To reach the arguments made above, I will first demonstrate why adoption is a relevant lens through which to see Anishinaabe citizenship law in the present. Towards such an end, this article begins with a discussion about treaty constitutionalism, or the fact that Indigenous legal orders continue to compete with Canadian legal orders for supremacy within

Lee, Adoption Narratives, supra note 6.

Specifically, the registration provisions of the Indian Act, supra note 1, ss 5-17.

Napoleon, "Indigenous Legal Orders," supra note 12 at 236.

Lawrence, supra note 10 at 73 .

Gloria Galloway, "Fort William First Nation Accepts Non-Indigenous Man as Full Member," The Globe and Mail (2 April 2017), online: <https://www.theglobeandmail.com/news/politics/non-indigenouscousin-in-fort-william-gets-full-first-nation-membership/article34558143/>.

37 By this, I wish to emphasize that my customary adoption is the actual basis of my belonging. While I am a member of the Fort William Indian band, my band membership is based on my customary adoption which took place outside the scope of section 10 of the Indian Act, supra note 1 or any other aspect of Canadian law. The Fort William band membership code merely recognizes this adoption, which took place in accordance with a different legal order. Interestingly, I believe that being made a band member in 2017 under the Fort William band membership code actually flattened my story in some ways many people no longer feel the need to hear my adoption story; the words "band member" seem to prove my belonging sufficiently. This is unfortunate. My customary adoption under Anishinaabe law is much more important to the resurgence of Anishinaabe legal orders than simply having my adoption recognized under a band membership code enacted under section 10 of the Indian Act. But this is a topic for a later article.

38 For useful discussions on identity-formation and Indigeneity within colonized contexts, see Sara Ahmed, Strange Encounters: Embodied Others in Post-Coloniality (London: Routledge, 2000); Eve Tuck \& K Wayne Yang, "Decolonization Is Not a Metaphor" (2012) 1:1 Decolonization: Indigeneity, Education \& Society 1, online: <decolonization.org/index.php/des/article/view/18630>; Philip J Deloria, Playing Indian (New Haven: Yale University Press, 1998); cf Damien Lee \& Kahente Horn-Miller, eds, "Special Edition on Adoption and Indigenous Citizenship Orders" 14:4 AlterNative [forthcoming], online: $<$ www.alternative.ac.nz/>. Not all Anishinaabeg will see me as someone who belongs. Moreover, some see me as Anishinaabeg, while others see me as merely a white man who lives with Anishinaabeg. See Tuck \& Yang, ibid for a useful discussion on how adoption has been used by non-Indigenous people to uphold settler colonialism in North America. Also see Sara Ahmed, ibid for an important discussion on identity consumption and the phenomenon of "being without becoming." Elsewhere, Deloria, ibid shows that "playing Indian" is a well-established colonial practice. 
Indigenous physical and political territories. ${ }^{39}$ Drawing on the work of Kiera Ladner, ${ }^{40}$ a Cree political scientist, I apply treaty constitutionalism as a methodology for reading the active presence of Anishinaabe law in Fort William daily life. Adoption, I argue, is merely a visible tip of an invisible ice berg; the bulk of Anishinaabe political authority and jurisdiction remains present though unseen. The lens of adoption, I argue, provides a way to see a system of collective judgment in matters of belonging. ${ }^{41}$ These latter sections of the article use stories shared with me through my dissertation research ${ }^{42}$ to show that Anishinaabe citizenship law is practiced by families in a decentralized and horizontal sense. ${ }^{43}$ I show that families establish a "provisional consensus" on who belongs, and this consensus is sorted out through a complex mix of individual and familial agency, whereby it is not simply enough for one family to adopt someone, but that an adoptee must demonstrate his or her commitment to the community over years or even decades. I conclude by arguing that, when seen through adoption narratives at Fort William, Anishinaabe citizenship law is decentralized in nature, and suggests a legal order that is active even if at times is not seen for what it is.

\section{THEORY}

\section{A. Treaty and Adoption Constitutionalism}

Treaty constitutionalism is a useful tool for identifying unseen constitutional orders at the interface between settler Canadian society and Indigenous nations. According to Ladner:

Treaty constitutionalism refers to the fact that there exists in Canada competing constitutional orders whereby both Indigenous and the Canadian constitutional orders and their respective nations claim jurisdiction over the same territory. Both claim that their right to do so is established by and grounded in history, law (their own domestic legal tradition and the wider systems of international law both pre and post 1537), international agreements (treaties), and their respective constitutions. ${ }^{44}$

In other words, while Canada presumes jurisdiction over Indigenous lands and polities, ${ }^{45}$ Ladner points to the fact that Indigenous nations have their own constitutional orders to manage their lives, territories, and affairs. ${ }^{46}$ Important to this definition is the argument that

Ladner, supra note 39 at 2.

46

Ibid. original]. First Nation.

Kiera L Ladner, “(RE)creating Good Governance Creating Honourable Governance: Renewing Indigenous Constitutional Orders" (Paper delivered at the Annual Conference of the Canadian Political Science Association, Ottawa, 27-29 May 2009) at 2.

Mills, supra note 19 at 865-66; Mills notes: “[u]nder a rooted vision of freedom, order isn't secured through rule of law; law isn't the formal obligation to respect rules (i.e., rights and correlative duties). Rather, [Indigenous] law consists in the informal responsibility to coordinate mutual aid (i.e., gifts and needs) within particular forms of relationship: law is a framework for proper judgment" [emphasis in

Lee, Adoption Narratives, supra note 6. In total, 13 knowledge holders shared their stories with me, each of whom belong with Fort William Indian Band and have direct experience with adoption. Some were adoptees, others were adopters, others still were descendants of adoptees brought into the community. Napoleon, "Indigenous Legal Orders," supra note 12 at 238. Similar to Napoleon's description of the Gitksan legal order taking place horizontally in a decentralized sense, I argue that Anishinaabe citizenship law frames decision-making in a similar sense when adoptees are brought into Fort Willaim

For example, through the assertion of section 91(24) of the Constitution Act, 1867, supra note 28 which states that affairs relating to "Indians, and lands reserved for the Indians" are under federal jurisdiction rather than under the domain of Indigenous nations themselves. Supra note 39 at 2. 
Indigenous and Canadian constitutional orders are "competing" with each other. ${ }^{47}$ This signifies an active presence; Indigenous legal and political orders are neither dead nor passive. They have life and can be drawn upon to guide the renewal of respective Indigenous nations in the present. ${ }^{48}$

When looking for evidence of Indigenous constitutionalism, Ladner points us to oral documents such as songs, stories, ceremony, orations, and ceremonial bundles. ${ }^{49}$ Other Indigenous scholars, such as Borrows and Youngblood Henderson, have identified constitutional orders within Indigenous languages. ${ }^{50}$ To me, such oral expressions of law are tips of constitutional icebergs, merely the audible portion of a deeper legal order. Ladner applies treaty constitutionalism to read on-going Indigenous political presence into section 35 of the Canadian Constitution Act, 1982, ${ }^{51}$ showing that the presence of intact Indigenous political systems is required to fully understand Canada's constitutional provisions as they relate to Aboriginal peoples. Without these systems, section 35 becomes a closed loop of settler (mis)recognition - endlessly echoing the state's vision of Indigenous rights rather than the substance of those rights being determined by the Indigenous nations' political systems themselves. ${ }^{52}$

I apply Ladner's work in this article to "see" Anishinaabe citizenship law at play through adoption narratives. ${ }^{53}$ Similar to the way in which treaty constitutionalism requires the existence of Indigenous constitutional orders to regulate practices such as hunting and fishing in ways that cohere with Indigenous political systems, I argue that adoption also requires the existence of a citizenship order to ensure the practice (adoption) is not only done correctly but contributes to the renewal of an Indigenous nation. But in order to explain this fully, I will first share my understanding of treaty constitutionalism. As seen in Figure 1, below, treaties often mention resource activities for both the Crown and the Indigenous nation. These activities might take the form of lumbering or mining, ${ }^{54}$ or various harvesting activities such as hunting and fishing. ${ }^{55}$ The constitutional basis to conduct such activities is often presumed, at least with respect to the Crown's side of the relationship. ${ }^{56}$ Treaty

$47 \quad$ Ibid.

$48 \quad$ Ibid at 4. Ladner writes: "Indigenous political systems were created and are maintained by a constitutional order which set forth a system of government, provided a defined and limited ability to make, interpret and enforce 'law' within a territory and set forth the rules of the 'political game' and the roles and responsibilities of all members of the nation."

$49 \quad$ Ibid at 2

50 Borrows, Constitutionalism, supra note 19 at 6-7; John Borrows, "Who Are We and How Do We Know?" (Presentation at Tribal Constitutions Seminar, Native Nations Institute for Leadership, Management, and Policy, University of Arizona, 2 April 2014), online: $<$ https://nnigovernance. arizona.edu/john-borrows-who-are-we-and-how-do-we-know> [Borrows, "Who Are We"]; Henderson, First Nations Jurisprudence, supra note 19.

Being Schedule B to the Canada Act 1982 (UK), 1982, c 11.

Ladner, supra note 39 at 15.

Ibid.

See e.g. Treaty 3 between Her Majesty the Queen and the Saulteaux Tribe of the Ojibbeway Indians at the Northwest Angle on the Lake of the Woods with Adhesions, 3 October 1873, online: <https://www. aadnc-aandc.gc.ca/eng/1100100028675/1100100028679>.

55 See e.g. Nicholas Xumthoult Claxton, "ISTÁ SĆIÁNEW, ISTÁ SXXOLE: 'To Fish as Formerly": The Douglas Treaties and the WSÁNEĆ Reef-Net Fisheries” in Leanne Simpson, ed, Lighting the Eighth Fire: The Liberation, Resurgence, and Protection of Indigenous Nations (Winnipeg: Arbeiter Ring, 2008) 47.

$56 \quad$ Patrick Macklem, "Ethnonationalism, Aboriginal Identities, and the Law” in Michael D Levin, ed, Ethnicity and Aboriginality: Case Studies in Ethnonationalism (Toronto: University of Toronto Press, 1993) 9 . 
constitutionalism provides us with a way to apply that same allowance to the Indigenous side of the treaty, as seen here:

FIGURE 1:

Treaty CONSTItUTIONALisM ${ }^{57}$

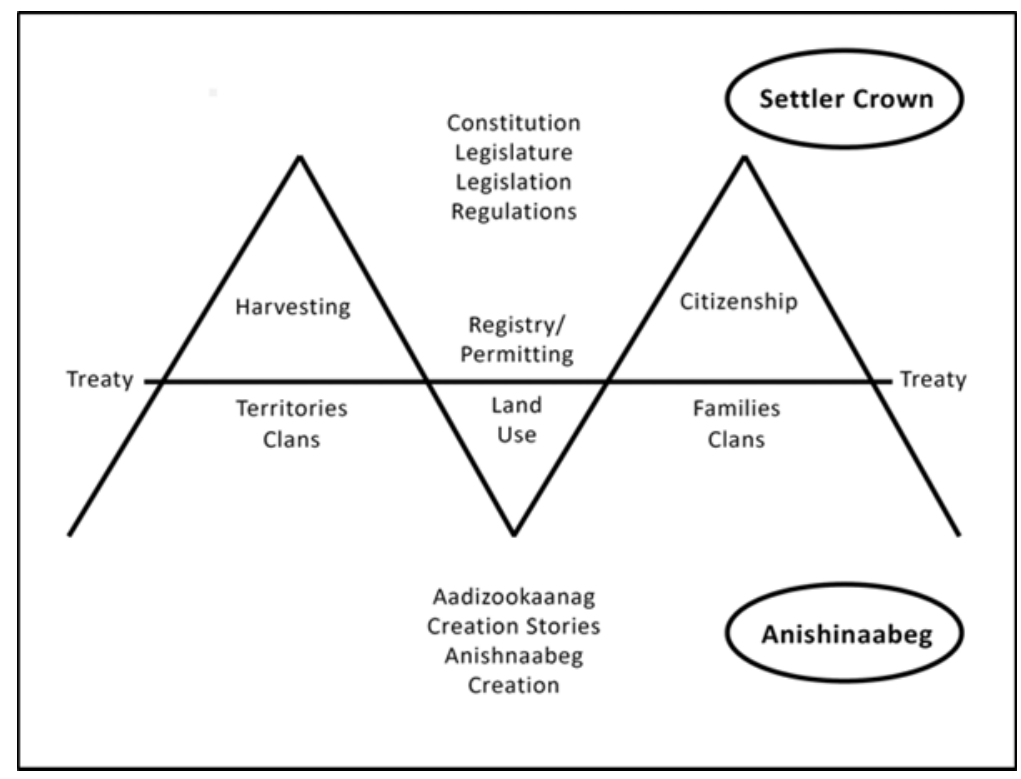

In this example, the settler Crown is presumed to bring its full constitutional weight to land use activities such as mining or lumbering. Such resource exploitation clauses necessitate a settler political order that would oversee and regulate these land-use activities, thereby necessitating an active constitutional order. In Figure 1, we see that "Land Use" is regulated by a permitting and registration system, which in turn is rooted in regulations, legislation, and so on. This may not be an exact model of how the state regulates land use, but it illustrates a point: lumbering, mining, fishing, and so on, are the visible practices guided by an invisible constitutional order that itself rests on the Crown's legal and political systems. Many in Canada would accept this matter-of-factly.

Conversely, Figure 1 also shows that Indigenous peoples bring their own constitutional orders to treaties as well. For example, just like the Crown's presumption of constitutional validity, Indigenous harvesting and citizenship practices are also guided by invisible legal and political orders. Harvesting practices, for example, might be regulated by families working within their respective Indigenous governance systems. ${ }^{58}$ While Crown land-use activities are regulated in part by the Crown's own legal and constitutional basis, ${ }^{59}$ so too are those activities regulated by the respective Indigenous nation. The treaty merely establishes 
a shared boundary; it does not relinquish one party's constitutional basis for governing itself in shared territory. ${ }^{60}$ The visible activities of one are not regulated by the invisible constitutional orders of the other.

To flesh out this point, I draw attention to the "Citizenship" peak in Figure 1. In this example, we can see that belonging - citizenship in a given Indigenous nation - is discerned by families and clans, which in turn are guided by aadizookaanag (sacred stories), and the like. In my community's treaty, for example, Anishinaabeg did not relinquish control over determining who belongs with them. In fact, they retained such authority. ${ }^{61}$ Again, this might not be an exact model, and it will not apply to all Indigenous nations, but it illustrates a point: Indigenous peoples' legal and political orders continue to exist and are no less valid, ${ }^{62}$ if unseen by some.

I would argue that treaty constitutionalism can be applied to reading Indigenous citizenship orders through adoption practices. Adoption is merely the visible practice (children joining families) that takes its form from underlying, invisible constitutional orders. As shown in Figure 2, below, adoption is guided by a constitutional order that is present, even if it is not readily seen. Again, this citizenship order is sui generis: it does not rely on Canadian Indian law for its function or legitimacy. ${ }^{63}$

Leanne Simpson, "Looking After Gdoo-naaganinaa: Precolonial Nishnaabeg Diplomatic and Treaty Relationships" (2008) 23:2 Wicazo Sa Rev 29.

61 Canada, Indigenous and Northern Affairs Canada, "Copy of the Robinson Treaty, Made in the Year 1850, with the Ojibewa Indians, of Lake Superior, Conveying Certain Lands to the Crown," online: $<$ www.aadnc-aandc.gc.ca/eng/1100100028978/1100100028982> [Robinson-Superior Treaty]. This

Treaty is very clear that "the Indians" will receive annuities only so long as

the number of Indians entitled to the benefit of this Treaty shall amount to two thirds of their present numbers (which is twelve hundred and forty) to entitle them to claim the full benefit thereof, and should their numbers at any future period not amount to two thirds of twelve hundred and forty, the annuity shall be diminished in proportion to their actual numbers.

In my mind, the only people who can determine the "numbers" of "Indians" in this scenario are

Anishinaabeg communities and families themselves. Anything less is settler colonial violence. 
FIGURE 2:

Adoption CONSTitutionalism

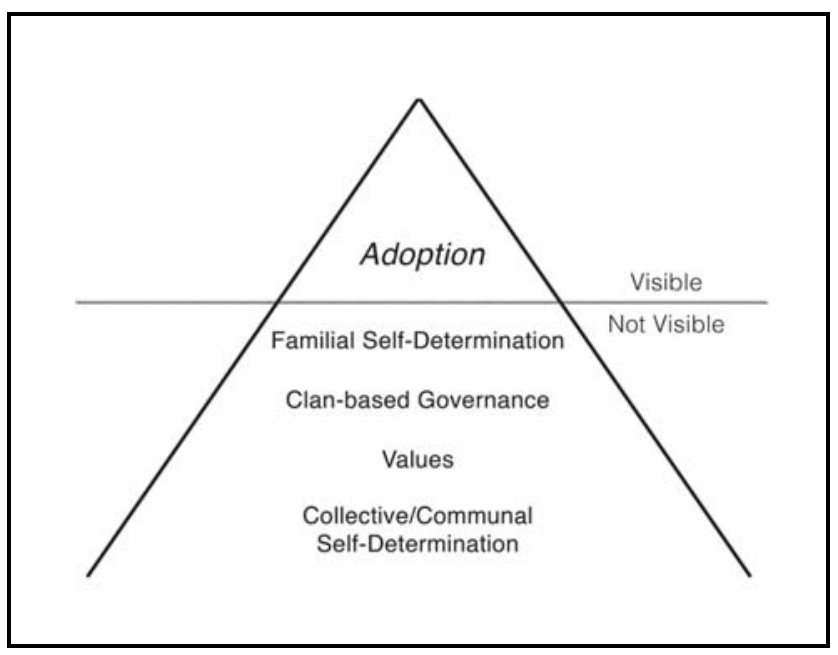

I refer to Figure 2 as "Adoption Constitutionalism" because it allows us to see the underlying citizenship order regulating the practice of claiming someone through adoption. As with treaty constitutionalism, adoption constitutionalism is useful as a methodology for reading the active presence of Indigenous citizenship law in the present. In this example, we see that adoption is the visible practice of familial self-determination, which in turn is based in a constitutional order that is outside the jurisdiction of the Canadian state. When families adopt someone at Fort William First Nation, for example, they are not simply claiming a child, but are also exercising a political-legal order rooted in Anishinaabe law. Others have drawn similar conclusions about the political function of adoption within Anishinaabe citizenship governance, ${ }^{64}$ while others still have simply referred to this as "customary" law. ${ }^{65}$ The Fort William knowledge holders (who I introduce in Part III, below) spoke to such Anishinaabe through their adoption narratives specifically.

It is worth noting that Indigenous peoples' approaches to their respective citizenshipmaking practices may not resemble mainstream definitions of citizenship. As Audra Simpson argues in relation to Kanien'kehá:ka citizenship-making at Kahnawà:ke, such practices “may not be institutionally recognized, but are socially and politically recognized in the everyday a New Emergence (Winnipeg: Arbeiter Ring, 2011) at 90.

65 See e.g. Larry Gilbert, Entitlement to Indian Status and Membership Codes in Canada (Scarborough, Ont: Carswell, 1996): Gilbert notes "[w]hen a statute [such as the Indian Act] recognizes custom adoption and the Constitution protects that aboriginal right, the aboriginal right includes not only the right to adopt children but, more important, the right to do so in accordance with the laws of those people" (ibid at 80 [emphasis added]). 
life of the community." ${ }^{\prime 66}$ As she notes in Mohawk Interruptus, her research suggests three findings that might be helpful when exploring issues of belonging today, namely,

(1) an alternative form of citizenship is being worked out [at Kahnawà:ke] through the everyday lives of community members, (2) historical memory is important, if not critical to this alternative form of citizenship, and (3) colonialism and "traditionalism" ... coalesce into these frames of reference within and beyond the boundaries of the reserve. ${ }^{67}$

In building on Simpson's question regarding how citizenship processes might be being worked out and relevant ${ }^{68}$ in my own community, the remainder of this article explores the ways in which an "alternative form of citizenship" ${ }^{69}$ is being worked out at Fort William First Nation, doing so through the specific lens of adoption narratives. As Simpson argues, belonging at Kahnawà:ke is a "narrated" process, one that "references personal and collective pasts while making itself over ... in a lived present." ${ }^{70}$ In this light, the adoption stories shared with me by Fort William knowledge holders opened a way to see the on-going presence of Anishinaabe citizenship law at play within the community.

\section{RESEARCH AT FORT WiLliAM FiRST NATION}

\section{A. Narrating Belonging}

As noted above, this article is based on research I conducted in my community for my $\mathrm{PhD}$ dissertation. I worked with 13 Fort William knowledge holders who shared adoption stories with me. Each of the knowledge holders were given monikers based on the 13 Anishinaabe seasons (for example, Zaagibagaa-giizis) to protect their identities. And each had direct experience with adoption, whether as adoptees themselves, parents of adoptees, or children of adoptees. Adoption was defined loosely - I spoke with individuals who had knowledge about adoptions taking place through provincial law or through Anishinaabe law. Both forms resulted in narratives of claiming and belonging that shaped the insights in this article.

For many of the knowledge holders I worked with, Indian status and band membership were points where discussions about belonging began. This makes a lot of sense considering the Indian Act's ${ }^{71}$ grip on interpellating Indigeneity as Indianness. ${ }^{72}$ Band membership, on the other hand, is somewhat trickier at Fort William because of its history. Put simply, there has been a lot of confusion about how membership is to be discerned at Fort William under the Indian Act. We are not alone in this. ${ }^{73}$ By way of context, in 1985 the Indian Act was

Audra Simpson, Mohawk Interruptus: Political Life Across the Borders of Settler States (Durham: Duke University Press, 2014) at 175 [Simpson, Mohawk Interruptus].

Ibid at 188 .

Ibid.

Ibid.

Ibid at 171.

Supra note 1 .

Lawrence, supra note 10 at 185.

Indian and Northern Affairs Canada, Impacts of the 1985 Amendments to the Indian Act (Bill C-31):

Module 1: Correcting Historical Wrongs? (Ottawa: Minister of Indian Affairs and Northern Development, 1990) at 24-26; Cameron v Canada (Indian Affairs and Northern Development), 2012 FC 579 [Cameron]. 
amended to allow Indian bands the option to control their own membership lists. ${ }^{74}$ According to section 10(8) of the Indian Act, once approved by the Minister of Indian Affairs, a band's membership code becomes the law governing membership decisions at a respective Indian band "from the day on which notice is given to the Minister." "75 The Fort William Indian band took advantage of this new legislation and accepted federal funding to develop its own membership code. ${ }^{76}$ On 26 June 1987, the electors of the band accepted a new membership code through referendum, ${ }^{77}$ which was then sent to the Minister of Indian Affairs. After some correspondence between the band and the federal government, the Minister of Indian Affairs gave notice to Fort William that "pursuant to subsection 10(7) of the Indian Act ... the Fort William Band has control of its membership effective June 26, 1987."”78

According to our code, Indian status is not a prerequisite for membership in the band, and adoption is grounds for membership. ${ }^{79}$ Yet, the Fort William membership code apparently was not used for nearly 30 years, and membership in the band seemed to depend on Indian status during that time. ${ }^{80}$ This practice effectively re-instituted Indian status in the Band's membership practices for nearly three decades, even where there was no obligation to do so. ${ }^{81}$ It was as if the 1987 membership code ${ }^{82}$ did not exist. This was a troubling scenario considering that when an Indian band that has opted to control its own membership list makes membership decisions outside its own membership code, it "act[s] outside of its jurisdiction and contrary to the rule of law." ${ }^{83}$ In November 2016, the Fort William Indian band recognized this failure and moved to implement its membership code as originally written and ratified in $1987 .{ }^{84}$ That said, confusion over band membership criteria abounded. As one knowledge holder, Namebini-giizis, put it in 2015, "I didn't even know: was there always a band membership code? Like, people we talked to over the years at the band office, should they know the code themselves?"85 Namebini-giizis adopted non-status children in the 1980s and had only recently found out about the existence of the 1987 membership code $^{86}$ by the time I spoke with him in 2015 .

Jack Woodward, Native Law (Toronto: Carswell, 1989) at 38-42.

Indian Act, supra note 1, s 10(8).

Indian and Northern Affairs Canada, Report to Parliament: Implementation of the 1985 Changes to the Indian Act (Ottawa: Minister of Indian Affairs and Northern Development, June 1987) at C-2 [INAC, Report to Parliament]; Membership Code, supra note 2.

Howard Bannon to Gene Bannon (1987).

Tom Siddon to Christi Pervais (1990).

Membership Code, supra note 2.

Fort William First Nation, "Fort William First Nation Citizenship Code: Renewal, Resurgence, ReMembering - Draft for Community Comment" (7 April 2015) at 1, online: <fwfn.com/wp-content/ uploads/2015/07/FWFN_Citizenship_Code_DRAFT_April-7-2015.pdf>.

81 INAC, Report to Parliament, supra note 76 at 12. Barring few limitations, section 10 of the Indian Act enabled Indian bands to make membership contingent on a very wide range of criteria, resulting in more than 220 slightly different codes. In 1987, Indian and Northern Affairs Canada cited the following limitations that draft membership codes had to abide before ministerial approval would be given: "[a] majority of electors must vote in favour of the band assuming control and in favour of the specific rules the band has developed. There are also provisions protecting the acquired rights of existing band members and those eligible to have membership in their band restored" (ibid).

Membership Code, supra note 2.

Cameron, supra note 73 at para 103.

Fort William Indian band, "Band Council Minutes: Fort William First Nation" (30 November 2016) at 3-4; Damien Lee, "Briefing Note: Fort William Band Council Resolutions re 1987 Membership Code," Zoongde (2016), online: < https://zoongde.com/ 2016/12/01/bcrbriefing/>.

85 Conversation with Namebini-giizis (2015).

${ }^{86} \quad$ Membership Code, supra note 2. 
Given the way band membership has been practiced by the Fort William Indian band for the past three decades, it is no wonder that complexities exist regarding what criteria the knowledge holders use to determine belonging in both a formal and informal sense. There were at least three logics at play outside of Anishinaabe citizenship law. First, Indian status has long been accepted as the threshold for determining who belongs and who does not. It showed up consistently during my dissertation research conversations as the knowledge holders made sense of belonging. For example, another knowledge holder — Zaagibagaagiizis - questioned why her own children could not be status Indians: "[A]ll my aunties have status. All their kids have status. [And all of] their kids have status. So why can't my kids have status? You know? They're entitled, too." ${ }^{87}$ Second, band membership appeared during my research conversations as well. As one knowledge holder - Gichimanidoo-giizis - shared about her grandchildren, "I've consistently sent letters to Fort William to get them registered as members. [I'm going to the] band council meeting [this month], just to do [this] membership thing." 88 Third and finally, bloodline appeared throughout the conversations as a criterion for discerning belonging with the band. Many spoke of blood as a key element of belonging at Fort William.

This is not to say that these three bases are not important. I do not wish to suggest that these do not have real effects on people's lives and/or how belonging is discerned today at Fort William. Rather, my point is that through their over-emphasis, Indian status, band membership, and ideas resembling blood quantum have come to obfuscate inherent Anishinaabe citizenship law at Fort William First Nation.

That said, for several of the knowledge holders, Indian status, band membership, and even bloodline-based logics of belonging began to fall apart as they tried to make sense of the adoption narratives they were carrying. While this unsettlement was evident in a number of conversations carried out in support of my research, one knowledge holder in particular was especially articulate on these matters. One morning in late January 2016, I sat with Iskigamizige-giizis ${ }^{89}$ talking about her family history as it pertains to adoption. Iskigamizigegiizis is recognized within Fort William as someone who carries community oral histories. ${ }^{90}$ Moreover, it should be noted that she occupies a unique place amongst the knowledge holders I engaged in my research. She is the only person I spoke with that is both the daughter of an adoptee and an adopter herself. In this sense, and due to Iskigamizige-giizis being recognized by the broader community as someone knowledgeable in Fort William's social and political history, I hold a great deal of respect for her words and insights on the topic of Anishinaabe citizenship law.

At one point in our conversation, Iskigamizige-giizis began comparing her own feelings about her mother's adoption, and the adoption of other children she knew in the community — including me. ${ }^{91}$ She was unsettled because, in some adoption cases, children belonged with Fort William without a bloodline connection, yet she regarded some other children with

Conversation with Zaagibagaa-giizis (2015).

Conversation with Gichimanidoo-giizis (2015).

Conversation with Iskigamizige-giizis (2016).

Conversation with Gashkadino-giizis (2016). Gashkadino-giizis suggested that I should speak with Iskigamizige-giizis precisely because of her knowledge about adoption and Fort William families.

Conversation with Iskigamizige-giizis, supra note 89. 
bloodline connections to the community as only tenuously belonging. ${ }^{92}$ How could it be that some people came to belong with the community over the years even if they did not have a blood lineage connection to Fort William? This unsettlement appeared several times, including in the following monologue:

I find it really hard because I'm loyal to my family. I love my family. And [my mother] grew up here, whatever. [She identified] as native. ... But, I mean really [name of someone] was adopted here, so. I don't know. That's a tough question. That is a tough question [sic]. And it's kind of like a Catch 22 a little bit. Because, ya, you wanna talk about First Nations blood being "full” but ... I remember my mom [talking] about how they never — back in the olden days, you know, if you were out here, you were like part of the family. You were brought in. You would take someone's name and not be even legally adopted. You'd just end up being Joe Blow Whoever, same as their name. So, I don't know, it's hard to say. You know? I mean, eventually, obviously, the bloodline runs out if ... you're not marrying into your people. Right? But, ya, [adoption is] a hard question. Like, I mean, I understand in your case, ${ }^{93}$ too - you know, you were raised out here also, and, you know ... you were always taken in as family... But I guess you could say, it could go both ways. I don't know. I'm still unsure. ${ }^{94}$

Clearly, something is not sitting well with her. As seen here, Iskigamizige-giizis was struggling to reconcile the concept that some people could belong while others could not due to their blood status (namely, whether an adoptee was known to have Indian blood or not). Yet, she was aware of her self-contradiction — her own "Catch 22" — where she would accept some adoptees yet have a hard time accepting others. ${ }^{95}$

In her research into how citizenship is discerned in her own community, Mohawk scholar Audra Simpson shares the concept of "narrating" citizenship to explain how families determine belonging and non-belonging on their own terms at Kahnawake. ${ }^{96}$ Simpson shows that some people are claimed through narratives of familial relationships. ${ }^{97}$ Such individuals are not status Indians but are nonetheless recognized by the people of that community as those who belong. Without a status card or some other "evidence" of belonging, their belonging is "proved" by the ways in which it is narrated. "[M]embership within a political community is more than a consequence of location, a matter of luck and birthplace," writes Simpson, ${ }^{98}$ "[it] is a social, historical, and ... narrated process that references personal and collective pasts while making itself over ... in a lived present... [Such] narratives of membership may work to build a sense of nationhood not from the signs and symbols of the state, but rather from the words and interactions of the people." 99

Applying the concept of narrating citizenship to Iskigamizige-giizis's example, we can see how she uses narrative to move through her own Catch 22. In the following transcript, ${ }^{100}$

Ibid.

Ibid; here Iskigamizige-giizis is speaking about the author, Damien Lee.

Ibid.

Ibid.

Simpson, Mohawk Interruptus, supra note 66 at 99.

Ibid at 150,171 .

Ibid at 171 .

Ibid [emphasis in original].

Conversation with Iskigamizige-giizis, supra note 89. 
we see that she resolves her unsettlement by upholding familial authority, specifically referencing her claim to me through family relations:

\begin{abstract}
Iskigamizige-giizis: Well, they get too, for a better word, "technical.” I mean, it's not technical, but, they start to dissect everything. Start saying "K, well, we gotta look at it this way: If, blah blah blah, he's got no native blood." Like, you know? And I'm guilty of this myself. [Like those other adopted] kids, raised out here. [Name of person] adopted them. And I'm guilty of saying those kids shouldn't have been entitled to our things. And I am guilty of it, because I have said that. You know? I mean, they too were raised out here. I don't know.
\end{abstract}

Damien: Well, what's the difference?

Iskigamizige-giizis: Ya! What is the difference? That's a good question. Its making me think now, right. What is the difference? You know? But maybe the difference, is, for you — for me to accept you ${ }^{101}$ — the difference is you're my family. [Damien laughing] You know what I mean? You're family. That's why. I would fight harder for you than for them.

Damien: Right.

Iskigamizige-giizis: You know what I mean?

Damien: Ya.

Iskigamizige-giizis: So, there's that loyalty coming back into play again. I would be more loyal to you in getting your, for you to have your status, adoption, whatever, than I would be for those kids.

Damien: Right. Because of family?

Iskigamizige-giizis: Because family. Because family [sic]. I mean, you may not be blood, but you're blood, because you're family. I mean, you're my cousin's son. Right? So, that's the difference. ${ }^{102}$

Iskigamizige-giizis's narrative shows how she moved past the cognitive dissonance associated with recognizing the belonging of some adoptees and not others. Instead of deferring to Indian status or band membership, for example, she instead re-grounds herself in a family's authority to claim individuals. This is evident in her statement "you're my cousin's son."103

I would argue that Iskigamizige-giizis resolved her Catch 22 by relying on Anishinaabe citizenship law. Her narrative demonstrates that belonging is contingent on more than just external recognition in the form of Indian status, for example, or immutable characteristics such as bloodlines. Rather, by working through her Catch 22, Iskigamizige-giizis was able to see familial authority - it was what helped her get past the Indian status and band membership logics we have gotten used to, but which also do not make much sense in terms 
of how things actually happen in the community. This is reflective of how John Borrows has discussed Anishinaabe citizenship law. ${ }^{104}$ As he puts it, Anishinaabe citizenship orders are based in the idea of having the freedom to own one's relationships. ${ }^{105}$ "Our word for 'citizenship'," he notes, "is dibenjigaazowin, the sense of almost a property-like type of responsibility, but not a western notion of property law where you alienate land or people from you, but a notion of Anishinaabe property law, which is about relationships and how we take responsibility for our relationships." ${ }^{\prime 10}$ The unsettlement and resolution Iskigamizige-giizis shared above speaks to this responsibility to own one's relationships; ${ }^{107}$ it evinces the freedom to do so beyond normative status quo logics. She was clearly unsettled by the possibility that belonging could be discerned outside of Indian status and bloodlines. But, if these logics were not hard and fast rules, then what bases should she use to determine belonging? Such unsettlements therefore act as sign posts, drawing our attention to some other force at play. That force, I argue below, is Anishinaabe citizenship law.

\section{B. Provisional Consensus}

One of the things I liked most about holding research conversations with the Fort William knowledge holders was the fact that, occasionally, I was meeting extended family members for the first time. Having grown up in the Fort William reserve, I was aware of people who I was related to but had never met. The reserve may be small, but this does not mean one will know everyone else, even cousins of varying degrees. This was the case with Waatebagaagiizis. She is my father's first cousin, and though I had attended elementary and high school with one of her children, I had never met her directly. Having heard about my research through her family members, she had agreed to meet with me to share parts of her family's stories about adoption at Fort William. But she did not do so before assessing who I was in relation to her. She used her familial network to learn about me. Other families confirmed that I belong with Fort William. In short, others vouched for me, and this mattered.

Whereas the previous section demonstrated how treaty constitutionalism could be used to see Indigenous legal orders, this section now explains some of the ways in which adoptees actually came to belong with Fort William through Anishinaabe citizenship law. As I show below, for adoptees at Fort William, belonging is determined collectively. It does not arise simply by one family claiming a child, as this would negate the self-determination of other families in having a say in who is claimed collectively. Instead, I would argue that their belonging was established through what Kirsty Gover has referred to as "provisional consensus." 108

As Gover has argued, Indigenous nations assert their own constitutional orders, of which citizenship is a part, through developing "provisional consensus within a tribal community, emerging from political processes of debate and contestation. ... [These] give shape to an indigenous concept of indigeneity and an indigenous-non-indigenous boundary." 109 In other

\footnotetext{
104 Borrows, "Who Are We," supra note 50, 9:19-10:38.

105 Ibid.

106 Ibid; see also Borrows, Constitutionalism, supra note 19 at 6-7.

107 Conversation with Iskigamizige-giizis, supra note 89.

108 Kirsty Gover, Tribal Constitutionalism: States, Tribes, and the Governance of Membership (New York: Oxford University Press, 2010) at 11. 
words, belonging is forged through the interplay of people and families claiming individuals, individuals claiming communities, and the tensions that come within this matrix of relationships.

At Fort William, my research shows that families decide amongst themselves who belongs. This inter-familial recognition sometimes overlaps with band membership and Indian status forms of recognition, but not always. Some adoptees who are band members and status Indians were ultimately rejected by the knowledge holders. ${ }^{110}$ In other instances, the knowledge holders accepted adoptees whom did not have membership or status. ${ }^{111}$ But, more importantly to this article, the Fort William knowledge holders narrated a citizenship governance system that was based on resolving a tension between individual families and the self-determination of the collective. ${ }^{112}$ On the one hand, individual families might adopt someone, and at times they narrated this as the threshold for fully belonging with the community. But they also shared stories about other families intervening on this singlefamily system.

During an interview with Onaabani-giizis, ${ }^{113}$ for example, this intervention was verbalized as resentment when community members inquired about her from time to time. Onaabanigiizis spoke of this quite clearly, stating "I don't feel obligated to tell people my story, but I feel like everybody feels like they are obligated to know it." 114 She referred to this interest as a negative experience for her and her family: "[1]ike, there is so much exclusion based on people knowing our story. And it's really none of their damn business. ... [T] hey just pass this judgment ... before they even know the whole story." 115 This process of others knowing her story was narrated as a source of uncertainty, akin to a "roller coaster" in that "no matter how much you push, its two steps forward, five steps back."116 Yet, people from the community continued to ask nonetheless. This is important, and I will return to it again below.

This tension is made more explicit by comparing the following polemic statements. In describing how adoptees are brought into the community, two knowledge holders argued what might be seen as opposing points. The first argued for a single-family system of discerning belonging, while the second argued for a system based on collective decisionmaking across families:

Firstly, it should always be the family that decides. Everyone should follow suit. Even for those who don't belong, families should make such decisions. ${ }^{117}$

Conversation with Odemiin-giizis (2015); Conversation with Manoominike-giizis (2015); Conversation with Gichimanidoo-giizis, supra note 88; Conversation with Manidoo-giizisoons (2016); Conversation with Gashkadino-giizis, supra note 90; Conversation with Binaakwe-giizis (2016).

Ibid.

Ibid.

Conversation with Onaabani-giizis (2015).

Ibid [emphasis added].

Ibid [emphasis in original].

Ibid.

Conversation with Odemiin-giizis, supra note 110. 
How do you come to consensus? ... [It's] like a cross group of all the different families ... that determines who's brought into the community. ${ }^{118}$

These quotes are interesting in that they lay out two poles in a citizenship governance system that I believe is much more amicable than dichotomous. Anishinaabe citizenship governance, I argue, is not an either/or scenario, where it is either one family that discerns someone's belonging or a cross section of families that do so. Rather, belonging is determined through both of these mechanisms at play at the same time. A family might adopt someone, but then other families have a say in whether the adoptee is ultimately claimed by the community (I return to this below). I believe this explains in part why Onaabani-giizis reported that everyone feels obligated to know her story - other families are checking in on her behaviour over time.

Juxtaposing the two quotes above brought the contours of Anishinaabe citizenship governance into relief for me. They suggest that there is a tension between an individual family's decision to adopt someone, and the broader community's self-determination to discern who actually belongs with the community. Furthermore, to me, this suggests that one function of Anishinaabe citizenship law is to resolve this tension in ways that promote community renewal while respecting collective self-determination. Whereas Borrows has argued that dibaajigenzowin is about the freedom to own one's relations, ${ }^{119}$ this tension between single families and the "cross group" of families in the broader community speaks to a decentralized citizenship governance system that seeks to resolve tensions in ways that serve community interests. When seen through adoption narratives, then, belonging is determined "with and through" others. ${ }^{120}$ Speaking to this constitutional principle of freedom, Mills argues that "individual's freedom, the freedom of [one's] community, and the freedom of all of its other members are mutually constitutive; each serves as an ongoing condition of the possibility of the other." "21 To me, this speaks to how Fort William families collectively practice Anishinaabe citizenship law: adoptees might be claimed by an individual family, but ultimately their belonging is discerned only with and through others.

Coming back to Onaabani-giizis's narrative for a moment, I read her experience with other families looking into her "business" as reflective of Gover's "provisional consensus."122 While Onaabani-giizis experienced such attention in a negative sense, I would argue that such interest is, in fact, a key element of Anishinaabe citizenship governance. Other families wanted to know if she is "us," and as I see it they performed a function that is not available through band membership and Indian status-based approaches to discerning belonging. They were checking to see if Onaabani-giizis was carrying herself in a good way.

My point here is not to single-out Onaabani-giizis. Indeed, she shared many stories about how her extended family and other Fort William families claim her as someone who generally, but I borrow his usage of "with and through" here as it helps to explain the way I see Anishinaabe citizenship law being practiced by Fort William families. I unpack this point further in the main body of this article.

Ibid.

Conversation with Onaabani-giizis, supra note 113; Gover, supra note 108. 
rightfully belongs. ${ }^{123}$ Rather, my point is to highlight a tension between parents, adoptees, and other families in the community. This tension is important because it demonstrates the self-determination of Anishinaabe families in discerning who belongs without relying on external legal orders such as Canadian law. It is not for Canada to decide who belongs with Anishinaabeg. Anishinaabeg at Fort William have never relinquished this authority. ${ }^{124}$ As I will argue in the next section, it is families that renew the Anishinaabe nation, not the Canadian government, nor Indian bands.

\section{INSIGHTS}

\section{A. Collaboration ANd Renewal}

In my analysis of the knowledge holders' stories, it was evident that Fort William families engage in establishing provisional consensus when discerning belonging. They spoke about evidence of belonging in different ways, but each time it had to do with inter-familial recognition rather than simply band membership or Indian status. This inter-familial recognition suggests that the families were participating - consciously or not - as actors in a system of collective decision-making. For example, Iskigamizige-giizis noted that belonging is evinced by having knowledge of the inner workings of the community. ${ }^{125}$ For her, this applied to both adoptees and those born into the community - even her own nephews. ${ }^{126}$ According to her, belonging could only be established through the work of establishing and maintaining such relationships: "you have to be enveloped into your surroundings ... to be accepted. Be in the hub [of the community]. Know." 127 She refused to recognize certain adoptees (and non-adoptees) who showed no interest in building genuine relationships with the community. ${ }^{128}$ Iskigamizige-giizis questioned the belonging of those who refused to "know" the community or put in the work of developing and maintaining good relationships. ${ }^{129}$

While the knowledge holders discussed a number of ways in which provisional consensus is established, two themes arose in particular. First, as noted above, it was established collaboratively (or co-constitutively) where parents, individual adoptees, and families decided jointly, though indirectly, on whether someone belongs. This way of discerning belonging was based in decentralized decision-making, vesting authority in a cross section of families and individuals that assessed adoptees for whether they carried their responsibilities to the community in a good way. Second, the knowledge holders showed that provisional consensus is also based on renewal (re-constitutive). The adoption narratives shared with me suggest that adoptees had to renew their relationships with individuals and the community on a continual basis. Again, belonging was not necessarily guaranteed simply because a family adopted someone. Rather, the knowledge holders spoke of some adoptees having to prove themselves over and over to the broader community for their acceptance to

Conversation with Onaabani-giizis, ibid.

Robinson-Superior Treaty, supra note 61.

Conversation with Iskigamizige-giizis, supra note 89.

Ibid.

Ibid [emphasis in original].

Ibid.

Ibid. 
be solidified. ${ }^{130}$ If they did so in a way deemed acceptable by the community, things got better over time. ${ }^{131}$ In short, belonging is renewed, not automatic or permanent.

As I show below, the tension being resolved at the centre of "provisional consensus" is one of socialization guided by mores, obligations, and expectations of community families. Adoptees at Fort William are given the chance to belong not only if they uphold the conventions of the community, but also if they demonstrate true allegiance to the community itself. The following two narrative threads unpack this process. First, the knowledge holders discussed the establishment of belonging co-constitutively in relation to riding the reservation school bus and going to school in the city of Thunder Bay, Ontario more generally. Indeed, the reservation school bus burst through the knowledge holders' stories on its own terms. In all cases except one, ${ }^{132}$ the knowledge holders who spoke of the school bus brought it up on their own volition. As Binaakwe-giizis put it, it was on the school bus where life-long social relations within Fort William were discerned. ${ }^{133}$ Yet, others showed that the school bus was also a site where they and their families felt exclusion because someone in their family was adopted. The school bus is thus a "thick" site in which Anishinaabe citizenship law at Fort William is made visible.

Second, the knowledge holders discussed the re-constitutive aspect of belonging through annual community events such as Christmas parties, summer camps, and the like. ${ }^{134}$ Remember, Onaabani-giizis spoke of having to prove her connection to the community over and over. ${ }^{135}$ This cyclical formation speaks to a larger framework of belonging in which families and the community in general assess an adoptee as to his or her willingness to affiliate with the community in genuine ways. To unpack the re-constitutive theme, I focus on the Fort William First Nation Remembrance Day ceremony - an annual event that has now, in part, come to define Fort William's identity as a community. Together, these narratives show that by discerning belonging through adoption, Fort William families are engaging in the practice of law, which Napoleon reminds us is not so much a "thing" but something that people do. ${ }^{136}$

\section{B. Belonging Is Co-Constitutive: THE RESERVATION SCHOOL BUS}

Narratives about the reservation's school bus refused to remain unspoken in the knowledge holders' stories about adoption and belonging at Fort William First Nation. Several people spoke of the school bus (or, more accurately, busses, as there are several) in ways that point to the way Anishinaabe citizenship law is practiced. It was discussed as a

Conversation with Abitaa-niibini-giizis (2015); Conversation with Waatebagaa-giizis, supra note 118. Ibid.

Namely, Conversation with Binaakwe-giizis, supra note 110. Here, I asked about the school bus specifically.

Ibid. As Binaakwe-giizis put it, it was on the school bus that the "pecking order" of social relations within Fort William was discerned.

Conversation with Waatebagaa-giizis, supra note 118; Conversation with Onaabani-giizis, supra note 113.

Conversation with Onaabani-giizis, ibid. Onaabani-giizis spoke of this quite clearly, stating "I don't feel obligated to tell people my story, but I feel like everybody feels like they are obligated to know it" [emphasis added].

Napoleon, "Indigenous Legal Orders," supra note 12 at 232. 
space in which the belonging status of adoptees was or is established. In short, one's belonging was or is highly influenced by whether an adoptee - or other children for that matter ${ }^{137}$ - participated in the social relations playing out within the school bus. Moreover, the importance of the school bus extended beyond discerning the belonging status of adoptees. Descendants of adoptees spoke of being excluded from the reserve because, at times, the community viewed their adopted parent as not Indian enough to belong. ${ }^{138}$ In other instances, knowledge holders questioned the belonging of children who were born to the community (who otherwise belong through bloodline) because they were not taking the school bus. ${ }^{139}$ I return to these points in this sub-section, but for now I emphasize that the reserve's school bus produced a physical and social space in which children mutually claimed each other, or not.

It is important to explain the reason why the reservation school bus resonated for many knowledge holders regardless of their age. Fort William is located immediately next to the city of Thunder Bay, Ontario, separated only by the Kaministiquia River. This landmark or watermark - serves to separate my community from settler society both geographically and metaphorically. We are from "the Mission" — the colloquial name for Fort William First Nation, a name given by a Jesuit Mission placed in our community to convert Anishinaabeg to Christianity in the early $1800 \mathrm{~s} .{ }^{140}$ We have internalized this name today. As far as I know, when asked, few people from Fort William would say they are from "Fort William." The majority would say they're from the Mission.

While today there is an internet-based high school located on the reserve, the majority of school aged children attend a variety of schools in the city. The closest elementary school is within a five-minute drive from the reserve, as is the closest high school. Yet, despite this physical closeness, there exists considerable social and political distances between the two communities. Thunder Bay is not devoid of anti-Indigenous racism, ${ }^{141}$ and this racism plays out at school as well as in other levels and spaces of society. Some knowledge holders spoke of children from Fort William not being allowed off the bus by city-based parents who did not want "Indians" going to their children's schools. ${ }^{142}$ Others spoke of needing to stick together on the school yard for safety. ${ }^{143}$

Conversation with Iskigamizige-giizis, supra note 89; Conversation with Binaakwe-giizis, supra note 110; Conversation with Gashkadino-giizis, supra note 90.

Conversation with Odemiin-giizis, supra note 110; Conversation with Manoominike-giizis, supra note 110; Conversation with Waatebagaa-giizis, supra note 118.

139 Conversation with Iskigamizige-giizis, supra note 89.

140 Fort William First Nation, The Importance of the Duty to Consult and Accommodate at 13, online: $<\mathrm{https}: / / \mathrm{fwfn} . c 0 \mathrm{~m} / \mathrm{wp}$-content/uploads/2016/12/FWFN_ConsultationBook-Nov2016-singlereduced.pdf $>$.

141 Robert Jago, "The Deadly Racism of Thunder Bay," The Walrus (11 December 2017), online: $<$ https://thewalrus.ca/the-deadly-racism-of-thunder-bay/>; Damien Lee, "Burning Bridges," Zoongde (30 October 2013), online: <https://zoongde.com/2013/10/30/burning-bridges/>; Libertarian Party of Ontario, "Tamara Johnson's Election Platform," The Chronical Journal (10 June 2014), online: $<$ bit.ly/2aFBn56>; Jody Porter, "Police Accused of Verbal Assault During Training Session on Missing, Murdered Indigenous Women," CBC News (13 September 2016), online: <www.cbc.ca/news/canada/ thunder-bay/thunder-bay-police-mmiw-training-1.3758791>.

Even [in] the city of Thunder Bay, you know that, unfortunately, Indians are painted with certain brushes.... Well, actually, my brother was telling me a story yesterday at my cousin's funeral about being called a "savage" when he was a kid. At the schools. When they closed the schools on the reserve and they bussed the kids into the city, city moms, he said, wouldn't let the Indian kids off the bus. For weeks, they drove around without being able to get off the bus. 
In this context, the school bus becomes more than a physical space in which children develop friendships with each other. It is a space in which fraternity is built in the face of needing to stick together to face a common threat: settler colonial racism and gendered violence. ${ }^{144}$ The result of this fraternity-building is a cohesiveness - a claiming of each other - that serves to increase the safety of the reserve's children in spaces that have proven to not always be safe for Indigenous individuals. Such claiming manifests in a verbalized motif that resonates with many people at Fort William today, as Binaakwe-giizis put it when describing his experiences riding the school bus as a child, the saying "[i]f you fight me, you fight the Mission" were words to live by while attending school in Thunder Bay. ${ }^{145}$ While I should not be understood to be suggesting that Anishinaabe citizenship law manifests only through traumatic experiences, this phrase is coded with meaning about claiming those who belong and thus deserves close consideration here.

A motif, defined as a "recurring salient thematic element (as in the arts) [or, especially] a dominant idea or central theme"146 acts as a truism that resonates broadly with a given community or group of people. When uttered, it conjures understanding without further explanation. The saying if you fight me, you fight the Mission, and its alternate forms, ${ }^{147}$ is a motif that resonates throughout Fort William social relations. When uttered, the phrase connotes a sense of belonging through fraternal relations. It suggests a togetherness and a strength in numbers that, when said, reminds its audience that the person speaking is claimed by the people of the reserve, and that the people of the reserve will make their presence known upon request. I have both used this phrase myself and witnessed its power when used by others. When uttered, the speaker is the reserve in a certain sense because they are speaking in collective voice. The saying simultaneously claims a person's relations and attests that their relations claim them back. The phrase if you fight me, you fight the Mission, then, speaks to an active presence that is hidden in plain sight: by the speaker claiming to be a part of the Mission, the listener is put on notice that there are people behind the speaker who will show themselves in solidarity and even go into the fray with and for them if a fight breaks out. ${ }^{148}$ This active presence goes beyond immediate family, and extends to the fraternity of relations that is developed through the spaces of co-constitutive claiming, such as the school bus. It is a verbalization of claiming and belonging that exists outside of, and challenges, Indian status and band membership frameworks: only those who belong through mutual claiming get to use this phrase and have it mean something. This is a visible or audible crest of an Anishinaabe legal order in that it speaks to the invisible relationships and fraternity that make it possible. In using it, then, the belonging of the speaker is both renewed and affirmed, partly because it connotes connectivity to the Mission, and partly because one will be expected to show up as "the Mission" the next time someone else uses it.

It is important for me to note here that, as a cis-gendered man who is phenotypically white, I have not experienced racialized and gendered violence directed at me specifically. Many of my family members, however, have experienced these forms of violence in the past and continue to experience them today. Conversation with Binaakwe-giizis, supra note 110.

Merriam-Webster, sub verbo "motif," online: $<$ https://www.merriam-webster.com/dictionary/motif $>$. A common alternate is "if you mess with me, you mess with the Mission." It connotes the same meaning as the phrasing cited in-text here.

Conversation with Binaakwe-giizis, supra note 110 . 
FIGURE 3:

THE Mission Bus ${ }^{149}$

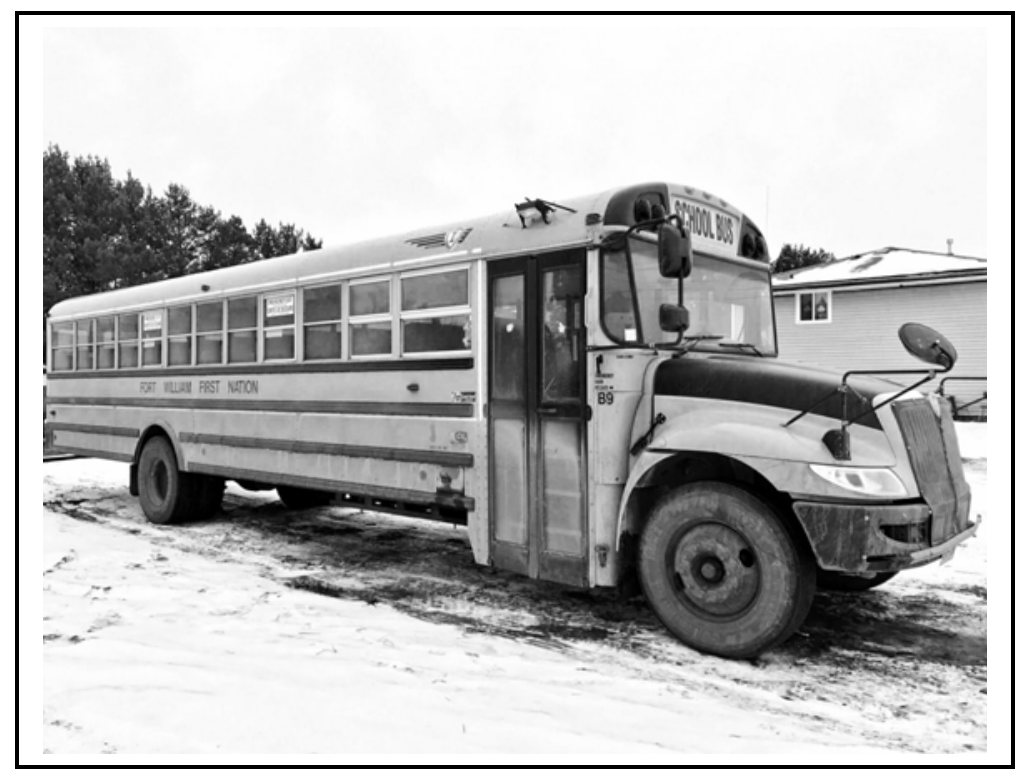

While there are other spaces in which such fraternity-building takes place, the school bus was discussed as a primary location for its fomentation (see Figure 3). This might be the case due to the visceral realness of being on a school bus together, leaving the reservation together, crossing the Kaministiquia River together, and then exiting the bus and heading into the school yard together as children, year after year. I make this observation as someone who spent years doing just this, and as someone who eventually drove the Mission bus as an adult. To borrow from Audra Simpson, the school bus is one space in which the relationality of "this is how I am, to you" is resolved. ${ }^{150}$ As such, one cannot discount the effects that the school bus and its collectively-lived experiences have on discerning belonging at Fort William First Nation. It is one of the spaces that gives rise to Anishinaabe citizenship law being narrated. It is one place we can look to see the continued existence of said law today.

Given the importance of the school bus and its role in building fraternity and social cohesion, it is no wonder then that some of the knowledge holders assigned considerable weight to it when explaining who belongs and who does not. This is why so many knowledge holders brought up the bus without being prompted — as a motif itself, riding the bus (or not) is loaded with meaning that requires little explanation in terms of assessing someone's belonging. Whether one rode the reservation school bus or not had a direct impact on how an individual's belonging was narrated, as the following stories make clear. 
The school bus was a site in which some of the knowledge holders sorted out which adoptees truly belong(ed) with Fort William, and which one's do or did not. Not all adoptees are claimed as rightfully belonging by the broader community. ${ }^{151}$ The adoptees that were seen to belong were those who rode the school bus and did other types of work to develop genuine relationships. The emphasis here is on the building of relationships, or what Iskigamizige-giizis called being "enveloped" in the community, ${ }^{152}$ and the bus is one way to speak about how relationships could be built in a genuine way. It is through building these relationships that one knows their place in the matrix of belonging in the community. For example, Iskigamizige-giizis questioned the belonging of her own extended family members on these very grounds: "I mean, my brother's kids lived out here all their lives, but are they in the hub? Well, [my cousin] might be now, right, because now she lives out in [Anishinaabekwe Bay]. But are her boys? See? Because, they don't catch the bus." 153 The school bus serves not only as a site of fomentation, but as a frame through which knowledge holders assessed who was being accountable to the community and who was not.

The importance of the school bus in confirming and mediating belonging was also shown in how access to it was regulated by the community. Odemiin-giizis, Manoominike-giizis, and Waatebagaa-giizis all spoke about the bus as a site of exclusion, a violence that had very real impacts on their lives for decades. ${ }^{154}$ They spoke of families in the community targeting them as children because their father was an adoptee. ${ }^{155}$ These knowledge holders recalled getting barred from the school bus because they were seen as too white on account of their father being non-native. ${ }^{156}$ Their father was adopted into Fort William as a child and grew up there fully accepted as someone who belongs. ${ }^{157}$ However, at some point, Fort William families decided to marginalize him and his family. At that time, they were living on the reserve, but their house was farther from town than most of the other children's. The way in which they were targeted for exclusion was through the school bus: it just stopped picking them up. ${ }^{158}$ They then had to rely on their older brother to give them a ride to and from school. This caused problems because their brother had to drop them off and pick them up according to his work schedule, which meant they were standing in the cold of winter for sometimes more than an hour. ${ }^{159}$ Odemiin-giizis and Manoominike-giizis made it clear that this exclusion was a result of their father being adopted, and that the exclusion was exercised by removing access to the school bus. ${ }^{160}$ This attitude towards their family persists today in some ways. Waatebagaa-giizis recounted what the Fort William Indian band told her recently when she was applying for her niece's band membership. According to her, the band responded by saying "“[w]ell, we're still having a little bit of trouble because of your dad's

Conversation with Iskigamizige-giizis, supra note 89.

Ibid.

Ibid [emphasis in original].

Conversation with Waatebagaa-giizis, supra note 118; Conversation with Odemiin-giizis, supra note 110; Conversation with Manoominike-giizis, supra note 110.

Conversation with Waatebagaa-giizis, ibid; Conversation with Odemiin-giizis, ibid; Conversation with Manoominike-giizis, ibid.

Conversation with Waatebagaa-giizis, ibid; Conversation with Odemiin-giizis, ibid; Conversation with Manoominike-giizis, ibid.

Conversation with Waatebagaa-giizis, ibid; Conversation with Odemiin-giizis, ibid; Conversation with Manoominike-giizis, ibid.

Conversation with Waatebagaa-giizis, ibid; Conversation with Odemiin-giizis, ibid; Conversation with Manoominike-giizis, ibid.

Conversation with Waatebagaa-giizis, ibid.

Conversation with Odemiin-giizis, supra note 110; Conversation with Manoominike-giizis, supra note 110. 
adoption.' And I thought '[a]re you frickin kidding me?' Because we're talking 80 years, you know, or 78 years at [that point in] my dad's life."161

Finally, it is also important to note that just riding the school bus did not and does not automatically mean one was claimed by others. A process of negotiation takes place in and around the bus in which children, through their labour of building relationships, claim each other (or not). "I'll use my brother as an example," noted Iskigamizige-giizis on this point. ${ }^{162}$ "His kids stayed over on [the other] side [of the reserve], didn't come to any of the programs, or didn't associate. The only association they did was, well, hockey — and they went on the bus - but they were never totally enveloped into the community. Like, they were always considered, kind of 'stuck up.' You know?"163 In this sense, the bus is a metaphor for genuine relationship building, or a tool for assessing accountability to the community. It was important to the degree that it allowed the knowledge holders to describe a person's belonging through their interest in relationship building. One could ride the bus while still being seen as only nominally belonging if they were also seen as "stuck up," or disinterested in Fort William.

The school bus is therefore a tool with which the work of building provisional consensus is resolved in regard to particular adoptees and other children. Riding the bus is not an absolute indicator of citizenship, but it demonstrates what the knowledge holders felt most important when determining belonging: allegiance to the people of Fort William. The school bus enabled the knowledge holders to make assessments without looking to external validation from the Indian Act. ${ }^{164}$ Indeed, as if to demonstrate the importance of the school bus in discerning belonging, the Fort William Indian band continues to link belonging and band membership with access to the school bus. As of autumn 2016, children must register with the band in order to be picked up by the Mission bus, stating in its weekly newsletter that "[families] must complete this form and return it to us or there will be no school bus service provided!" 165 The reserve's school bus thus continues to act as a symbolic site in terms of discerning who belongs, and one in which families continue to intervene as they work to control who has a chance to "know" the community.

\section{Belonging Is Re-Constitutive: REMEMBRANCE DAY AND FrankIE BANNING}

While the knowledge holders used the reservation school bus to explain why some people belong and others do not, they also spoke about events in the community where belonging is renewed on a cyclical basis. To me, the school bus represents a space in which belonging is co-constituted through relationship building. However, leaving the discussion there would suggest that belonging is established immediately or to say that simply riding the bus once is enough to say someone belongs. This would be inaccurate. Such a framing would obscure the role that other families play in discerning who belongs. The knowledge holders spoke

\footnotetext{
161 Conversation with Waatebagaa-giizis, supra note 118.

162 Ibid.

163 Conversation with Iskigamizige-giizis, supra note 89.

164 Supra note 1.

165 Fort William First Nation, "2016-2017 Fort William First Nation School Bus Registration Form” in Fort William First Nation: Weekly Newsletter (29 August 2016), online: <https://fwfn.com/wp-content/ uploads/2016/08/August-29-September-4.pdf $>$ [emphasis removed].
} 
about adoptees having to prove their allegiance to the community over time. This suggests to me that renewal is also important in terms of discerning who belongs. The knowledge holders shared stories through which the belonging of adoptees was renewed over and over again. This sub-section, therefore, considers such renewal. Here, I focus on one event in particular, namely, the Fort William Remembrance Day ceremony where the same adoptee is claimed over and over again every year. This event, I argue, provides the people of Fort William the chance to decide whether to renew their claims over them on a cyclical basis and, in turn, provides that same adoptee the opportunity to renew his claims to the community. Renewal in this sense is about claiming mutual ownership over each other over time.

My great grandfather, Jacob Bannon, adopted Francis (Frankie) Banning and Lyla Fasano as young children in the 1930s. Jacob took them in as his own children when he married their mother, May Bannon (née Humby). May was English, whereas Frankie and Lyla were from an Italian family living across the river in the city of Thunder Bay. From the date of their adoption, Frankie and Lyla lived in the Fort William reserve. Both passed away in 2010 as recognized elders within the community. ${ }^{166}$

As a war veteran, ${ }^{167}$ Frankie noticed that Anishinaabeg had no place of their own to commemorate war service. They had to squeeze into Remembrance Day ceremonies held and organized off-reserve, in spaces devoid of recognition tailored to Indigenous vets. ${ }^{168}$ So in 1995 he began a new tradition — he instituted an annual Remembrance Day ceremony near the Fort William pow wow grounds atop of Anemki Wadjiw ${ }^{169}$ — a sacred site within Anishinaabe Aki. Frankie invited Anishinaabeg and other Indigenous veterans and their families to attend, though all were welcome. ${ }^{170}$ Today, Fort William continues this tradition, despite the fact that Frankie passed away some years ago. ${ }^{171}$

The way I read this, is that Frankie - someone who was not Anishinaabe at birth, but who came to belong with Anishinaabeg through adoption — renews his claim to Fort William First Nation every year on November 11 th, even though he is no longer with us. The Remembrance Day ceremony acts as an opportunity for the broader community and Frankie to come together to renew their relationship. Each year, this space enables both to express their agency, to decide whether they want to renew their ownership over each other. This ownership is never guaranteed, even for someone like Frankie who spent his life caring for (and being cared for by) the community. It is not guaranteed because both the community

"Francis Fasano Banning (Obituary)," The Chronical Journal (2010), online: $<$ bit.ly/2aFl5t3 $>$ [Banning (Obituary)]; Blake Funeral Chapel, "Lyla Bannon: 1924-2010 (Obituary)" (2010), online: <bit.ly/ 2BO7wdD >; Conversation with Waatebagaa-giizis, supra note 118; Conversation with Iskigamizigegiizis, supra note 89.

167 "Aboriginal Veterans Tribute Honour List Surnames A to K," online: <www.vcn.bc.ca/ jeffrey1/ tribute.htm>. This website includes the following notations next to Frank Banning's name: "Fort William First Nation - Ont., Ojibway, WWII, Pte. Lake Superior Scottish Reg. | active overseas 2 nd wave D-Day." Conversation with Waatebagaa-giizis, supra note 118. "Francis Banning (Obituary)," tbnewswatch.com (22 February 2010), online: <https://www.tbnews watch.com/obituaries/francis-banning-382110>.

Conversation with Waatebagaa-giizis, supra note 118.

Nicole Dixon, "Remembrance Day Honours Fallen Soldiers," tbnewswatch (11 November 2016), online: $<$ https://www.tbnewswatch.com/local-news/rememberance-day-honours-fallen-soldiers-462022>; Banning Obituary, supra note 166. 
and Frankie - though now passed on - can always decide to not renew their claims to each other, thus respecting the self-determination of both parties as a result.

As it happens, Fort William does (re)claim Frankie each year at this event. While this was more readily understood when Frankie was alive and attending the ceremony between the years 1995 and 2010, this (re)claiming continues to be performed. The Fort William knowledge holders spoke about this continued (re)claiming in terms of affirmation. They told me stories about Frankie attending the ceremony in the form of an eagle or eagles. As Manidoo-giizisoons put it:

So, this year [2015], we were up the mountain and, same thing — because the last year, seeing the six eagles, I'm up the mountain this year, and I'm looking around, looking around [sic], and I don't see nothing. And I'm kind of disheartened a little bit. I'm like "[a]we." And then I looked over my shoulder, and there was one eagle, sitting there on the edge of the cliff at the very top [of Anemki Wadjiw]. And he sat there for two or three minutes. It wasn't the whole time, but he sat there for a while and the eagle just sat there and watched. And was literally sitting there looking down and going like this [gestures with head]. You could see him doing this. And then he flew away, around ... to the back side [of the mountain], right. And I didn't see him again. And I looked around, and I see everybody else, and they're all looking, and they were watching. You know that they saw it. And then everybody said "[t]hat must have been [Frankie]." That was everybody's feeling; that he was watching over; he's looking down, right. ${ }^{172}$

This sense of spiritual affirmation of Frankie's presence after his death was important not only to Manidoo-giizisoons, but to others as well. ${ }^{173}$ Indeed, of the knowledge holders I spoke to regarding Frankie and the Remembrance Day ceremony, nearly all spoke of eagles showing up and their connection to him. ${ }^{174}$

I would argue that such affirmation is a continuation of a cyclical renewal process between Frankie and the broader community. The Remembrance Day ceremony enables the community's leadership to (re)claim Frankie on a perennial basis, even after he has passed on. As was reported in November 2016, for example, "[e]ach Remembrance Day, [Fort William Chief Peter] Collins takes a minute to remember his uncle, Frank Banning, who kept the spirit and the commitment of the war veterans alive on Mount McKay for 21 years, even though he has gone onto the spirit world."175

Think about it this way: a person who came to belong with Anishinaabe through adoption instituted a new tradition that my entire community now comes to identify with. This is affirmed in ways beyond the presence of eagles and statements by the Chief; the band has dedicated annual funding exclusively for the ceremony, committing thousands of dollars for equipment and providing lunch for hundreds of people each year. ${ }^{176}$ Furthermore, collectively, the community is intensely proud of this tradition. ${ }^{177}$ Through all of these measures, Fort William First Nation collectively (re)claims Frankie each year at the

\footnotetext{
172 Conversation with Manidoo-giizisoons, supra note 110 [emphasis in original].

173 Conversation with Miin-giizis (2015); Conversation with Waatebagaa-giizis, supra note 118.

174 Conversation with Miin-giizis, ibid; Conversation with Waatebagaa-giizis, ibid; Conversation with Manidoo-giizisoons, supra note 110.

Dixon, supra note 171 .

Conversation with Waatebagaa-giizis, supra note 118.

Dixon, supra note 171 . Also see Figures 4 and 5.
} 
Remembrance Day ceremony. This is also the time that knowledge holders narrated his reciprocal claim to the community; whether in the form of stories about him starting the ceremony and attending it while he was alive, or about him continuing to attend it in the form of eagles now, Frankie still re-affirms his claim to Fort William in the minds of the knowledge holders who spoke of him. Indeed, the Fort William Indian band expressly claims Frankie today by honouring him in the Fort William First Nation Community Achievement Awards hallway in the reserve's community centre. He is narrated officially as a "band member of Fort William First Nation" without mention to his adoption status (see Figures 4 and 5). ${ }^{178}$

FIGURE 4:

FORT WILLIAM FIRST NATION COMMUNITY

ACHIEVEMENT AWARDS "HALL OF FAME"179

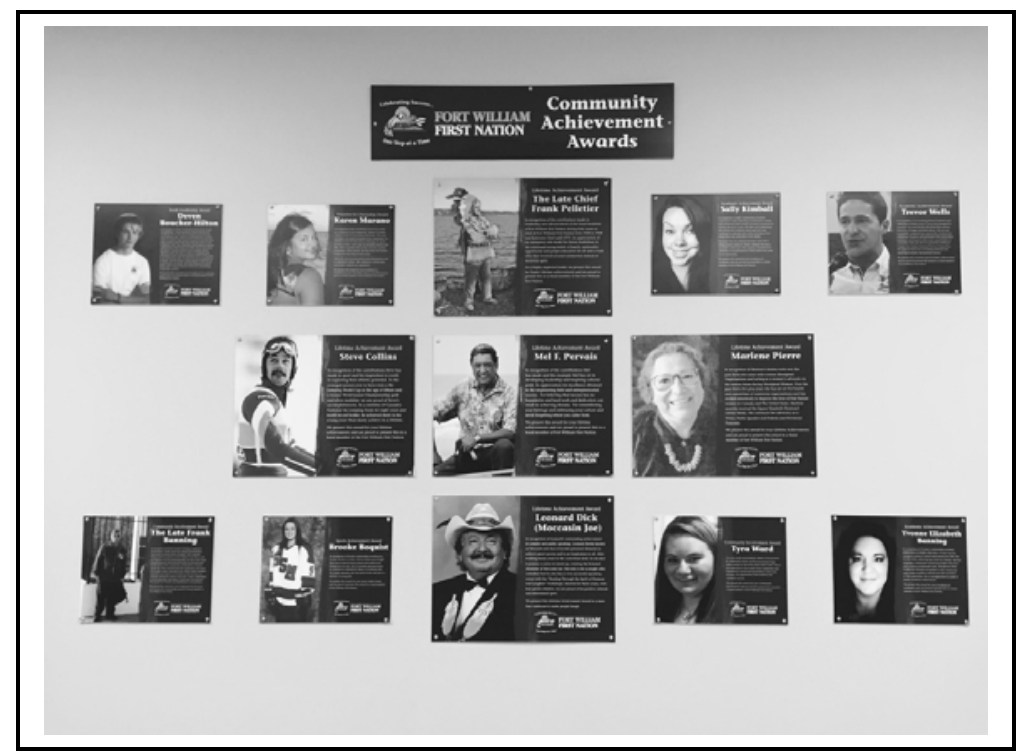

Fort William First Nation, "Community Involvement Award: The Late Frank Banning." See Figure 5 in this article.

179 Frankie Banning's plaque is located in the bottom row, furthest to the left. The Hall of Fame can be found in the main hall of the Fort William First Nation community centre. Photo taken by Damien Lee, 29 May 2016. 
FIGURE 5:

COMMUNITY INVOLVEMENT AWARD - THE LATE FRANK BANNING ${ }^{180}$

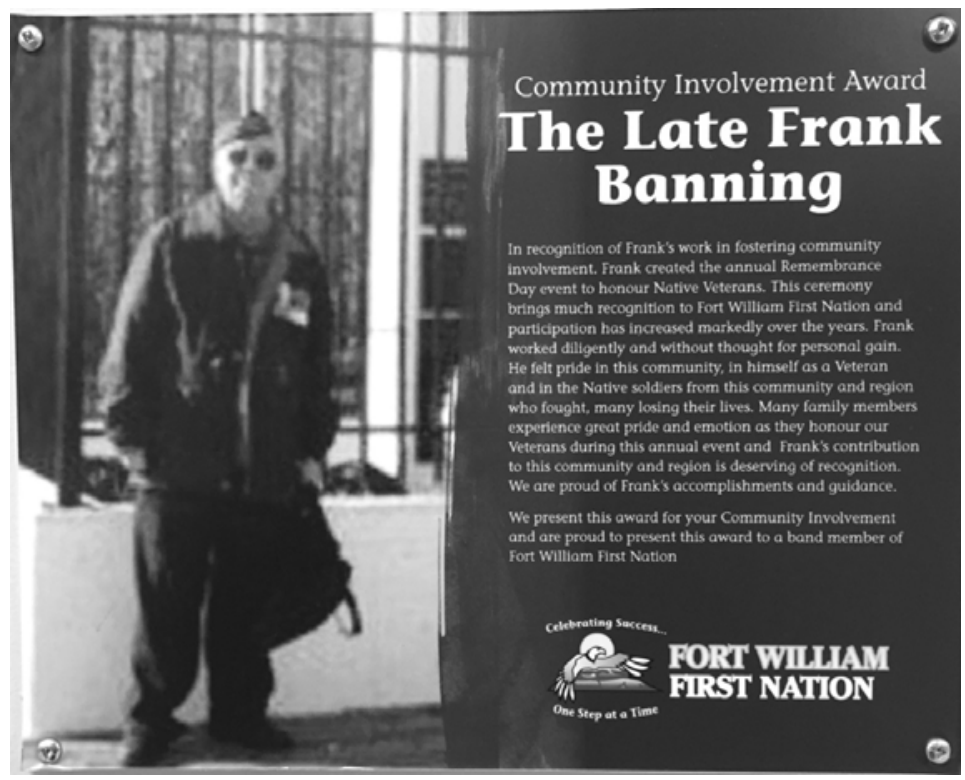

But perhaps the most solid confirmation of the community's claim to Frankie Banning comes in how his relationship with the community is narrated by the people of Fort William. Waatebagaa-giizis argues that Frankie's position as someone who belongs with Fort William is indisputable because so many leaders over the years have accepted the Remembrance Day ceremony:

Well, I think that the recognition that the chiefs - because it's been on for so many years, the 20 years of the service - there's been multiple changes in chiefs. They've all, I think, embraced [the Remembrance Day ceremony]. Some of them more so than others. But they've all accepted it and embraced it. And so, that tears down the barrier that there was ever any dispute about whether [Frankie] belonged or not. ${ }^{181}$

While the Remembrance Day ceremony does not encapsulate all of Frankie's life experiences, and while he cared for the community in many other ways, it nonetheless demonstrates a space where he and the community work through their claim to each other on a cyclical, perennial basis. 


\section{CONCLUSION}

The adoption stories shared by the knowledge holders narrate familial jurisdiction over citizenship. Families use adoption to regulate citizenship by intentionally bringing new citizens into the nation while also deciding who does not belong. As with other aspects of Indigenous legal orders, familial jurisdiction over citizenship can be both "implicit and explicit." 182 The act of citizenship making, taking various forms, can be expressed in the visual form of adopting a child, but this is animated on underlying layers of law that are invisible (see Figures 1 and 2 above). Familial jurisdiction over citizenship, then, is performative, but is not confined to sexual self-determination. Anishinaabe citizenship law is vested in families as actors that make political decisions within the nation. In this context, these decisions determine who belongs and who does not. Such a system of affirmation is different than a Certificate of Indian Registration (a "status card") in that it requires collective action rather than merely individual self-identification. This collective action reflects what Mills has discussed as a collective and performative freedom, where people experience freedom collectively "with and through others." ${ }^{\text {"183 }}$ Such freedom is "mutually constitutive," 184 which manifests in Fort William when adoptees, their parents, and broader families work out belonging internally rather than by relying exclusively on some external intervention (Indian status). As one knowledge holder put, "that's why [Anishinaabe] custom is good: there's no having to go sign papers, get lawyers, go to the white man's court. Nothing. Because our law is our law."

In this article, I set out to explain how Anishinaabe citizenship law is practiced in the Fort William First Nation as seen through the lens of adoption stories. The article establishes two points that must be considered when thinking about inherent Anishinaabe citizenship law. First, families have their own authority in discerning who belongs, and they will protect their self-determination by claiming and protecting their children. The knowledge holders I worked with made it clear that they have a familial jurisdiction when it comes to claiming individuals not only with them as families, but also with Fort William First Nation and the larger Anishinaabe nation.

Second, what all this tells me is that belonging at Fort William is not dependent solely on blood quantum, Indian status, or a band membership regime as imagined under section 10 of the Indian Act, ${ }^{186}$ but rather that the community actively engages in discerning belonging as well through an interplay between families, individual adoptees, and broader community processes. I argued above that this interplay establishes a "provisional consensus" on determining who belongs, and that this consensus is not limited to essentialized notions of Indianness. This consensus rests on whether adoptees demonstrate accountability to community on an on-going basis. The adoption narratives shared above show that within Anishinaabe citizenship orders, no one person or entity has ultimate power to discern who belongs. Instead, belonging is discerned in a decentralized sense, where claims to owning 
community and adoptee are renewed over and over, and where the behaviour of the adoptee factors into whether they are narrated as someone who belongs.

Seen in this way, adoption narratives reveal a citizenship order that challenges Canada's claimed jurisdiction to discern who belongs with Indians. Looking at such narratives and the legal principles that animate them is one way to "see" Indigenous peoples' constitutional orders at play in the present. Further Indigenous legal research could consider what Indigenous citizenship orders look like through other family-making practices, such as birthing traditions and marriage laws, while ensuring such work is considered through culturally appropriate means. ${ }^{187}$ Indigenous families renew their nations, not Canada nor Indian bands. And as such, it only makes sense to look to them when promoting the resurgence of Indigenous citizenship orders today. 